\title{
Pyrrolidine-5,5-trans-lactams. 5. Pharmacokinetic Optimization of Inhibitors of Hepatitis C Virus NS3/4A Protease
}

\author{
David M. Andrews ${ }^{a \star}$, Michael C. Barnes, Mike D. Dowle, S. Lucy Hind, Martin R. Johnson, Paul S. \\ Jones, Gail Mills, Angela Patikis, Tony J. Pateman, Tracy J Redfern, J. Ed Robinson, Martin J. \\ Slater and Naimisha Trivedi.
}

GlaxoSmithKline Medicines Research Centre, Gunnels Wood Road, Stevenage, SG1 2NY, UK.

david.andrews@astrazeneca.com

\section{Supporting Information}

\begin{tabular}{|c|c|c|c|}
\hline \multicolumn{4}{|c|}{ ABBREVIATIONS } \\
\hline DCC & Dicyclohexyl carbodiimide & TLC & Thin layer chomatography \\
\hline $\mathrm{CBZ}$ & Benzyloxycarbonyl & SPE & Solid phase extraction \\
\hline TFA & Trifluoroacetic acid & $\mathrm{SiO}_{2}$ & Silica \\
\hline THF & Tetrahydrofuran & $\mathrm{h}$ & Hours \\
\hline $\mathrm{BOC}$ & tert-butyloxycarbonyl & Min & Minutes \\
\hline DMSO & Dimethyl sulphoxide & Quant & Quantitative \\
\hline DCM & Dichloromethane & Equiv. & Equivalents \\
\hline & & $\%$ Th. & Percent of theoretical yield \\
\hline $\begin{array}{l}\mathrm{BF}_{3} \cdot \mathrm{OEt}_{2} \\
\mathrm{tBuMgCl}\end{array}$ & \multicolumn{3}{|c|}{$\begin{array}{l}\text { Boron trifluoride diethyl etherate } \\
\text { tert butyl magnesium chloride }\end{array}$} \\
\hline LiHMDS & \multicolumn{3}{|c|}{ Lithium bis (trimethylsilyl) amide } \\
\hline $\begin{array}{l}\text { HATU } \\
\text { HPLC }\end{array}$ & \multicolumn{3}{|c|}{$\begin{array}{l}\text { O-(7-azabenzotriazol-1-yl)-N,N,N',N'-tetramethyluronium hexafluorophosphate } \\
\text { High Performance Liquid Chromatography }\end{array}$} \\
\hline
\end{tabular}

\section{Chemistry}

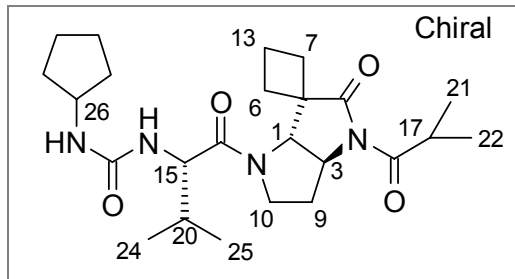

${ }^{a}$ Current address AstraZeneca, Alderley Park, Macclesfield, Cheshire, SK10 4TG, UK.

${ }^{1}$ Andrews, D.M.; et al. Org. Lett. 2002, 4, 4479.
N-cyclopentyl-N'-((1S)-2-methyl-1-\{[(3a'R,6a'S)-1'-(2-methylpropanoyl)-2'oxohexahydro-4'H-spiro[cyclobutane-1,3'-pyrrolo[3,2-b]pyrrol]-4'-

yl]carbonyl\}propyl)urea (4d)

Amine hydrochloride (3a'R,6a'S)-1'-(2-methylpropanoyl)-4'-L-valylhexahydro2'H-spiro[cyclobutane-1,3'-pyrrolo[3,2-b]pyrrol]-2'-one (5d) (prepared similarly to the earlier reported amine hydrochloride $5 \mathrm{a})^{1}(6.89 \mathrm{~g}, 18.5 \mathrm{mmol})$, was dissolved in dichloromethane $(130 \mathrm{~mL})$ and triethylamine added $(7.7 \mathrm{~mL}, 55.2$ mmol, 3 equiv.). A solution of cyclopentylisocyanate $(2.7 \mathrm{~mL} 24.6 \mathrm{mmol}, 1.3$ eq.) in dichloromethane $(30 \mathrm{~mL})$ was added with continuous stirring over a period of 15 minutes. The resulting solution was stirred at room temperature for 30 minutes. The reaction was quenched by the addition of $0.5 \mathrm{M}$ hydrochloric acid $(200 \mathrm{~mL})$. The resulting mixture was shaken vigorously, the 


\begin{tabular}{|c|c|}
\hline$\underbrace{26}_{24}$ & $\begin{array}{l}\text { layers separated and the organic layer washed with brine }(200 \mathrm{~mL}) \text {, dried over } \\
\text { sodium sulfate and evaporated to yield a crispy foam which was purified by } \\
\text { silica column chromatography, eluting with ethyl acetate:pet.ether (40/60) 1:1. } \\
\text { Fractions of interest were pooled and evaporated to yield } 4 \mathrm{~d} \text { as a crispy white } \\
\text { foam }(7.06 \mathrm{~g}, 86 \% \text { Th.) } \\
{ }^{1} \mathrm{H} \text { NMR }\left(\mathrm{CDCl}_{3}\right) \delta 5.8(\mathrm{~d}, \mathrm{~J}=8.5 \mathrm{~Hz}, 1 \mathrm{H}, \mathrm{NHCONH}), 4.82(\mathrm{~d}, \mathrm{~J}=7 \mathrm{~Hz}, 1 \mathrm{H} \text {, } \\
\mathrm{NHCONH}), 4.49,4.39(\text { pseudo t, J = } \sim 9.5 \mathrm{~Hz}, 1 \mathrm{H}, \mathrm{t}, \mathrm{J}=8.5 \mathrm{~Hz}, 1 \mathrm{H}, 15,10) \text {, } \\
3.94(\mathrm{~m}, 1 \mathrm{H}, 26), 3.84\left(\mathrm{~m}, 1 \mathrm{H}, 10^{\prime}\right), 3.61(\mathrm{~m}, 1 \mathrm{H}, 17), 3.42(\mathrm{~m}, 1 \mathrm{H}, 3), 3.24(\mathrm{~d} \text {, } \\
\mathrm{J}=10.7 \mathrm{~Hz}, 1 \mathrm{H}, 1), 2.92(\mathrm{~m}, 1 \mathrm{H}, 7,), 2.77(\mathrm{~m}, 1 \mathrm{H}, 9), 2.58(\mathrm{~m}, 1 \mathrm{H}, 7), 1.86- \\
2.19(\mathrm{~m}, 8 \mathrm{H}, 6,9,13,20, c P e n \times 2), 1.57(\mathrm{~m}, 4 \mathrm{H}, c P e n), 1.32(\mathrm{~m}, 2 \mathrm{H}, c P e n) \text {, } \\
1.18(\mathrm{~d}, \mathrm{~J}=7 \mathrm{~Hz}, 3 \mathrm{H}, 24), 1.16(\mathrm{~d}, \mathrm{~J}=7 \mathrm{~Hz}, 3 \mathrm{H}, 25), 1.04(\mathrm{~d}, \mathrm{~J}=7 \mathrm{~Hz}, 3 \mathrm{H}, 21) \\
1.02(\mathrm{~d}, \mathrm{~J}=7 \mathrm{~Hz}, 3 \mathrm{H}, 22) \\
\mathrm{Mass} \mathrm{spec} \mathrm{MH}^{+}(\text {found, electrospray }+\mathrm{ve}) 447 \\
\mathrm{MH}^{+}\left(\mathrm{calculated} \text { for } \mathrm{C}_{24} \mathrm{H}_{38} \mathrm{~N}_{4} \mathrm{O}_{4}+\mathrm{H}\right) 446.595\end{array}$ \\
\hline
\end{tabular}

\section{Abridged Characterization Data}

\section{Methods :}

NMR spectra $\left({ }^{1} \mathrm{H} 400 \mathrm{MHz},{ }^{13} \mathrm{C} 100 \mathrm{MHz}\right)$ were recorded on a Bruker DRX400, Bruker DPX400 or Varian Inova400 spectrometer. Chemical shifts $(\delta)$ are reported in ppm and coupling constants $(J)$ in $\mathrm{Hz}$. In $\mathrm{CDCl}_{3}$ chemical shifts were referenced using TMS as an internal standard or in $d_{6}$-DMSO using the residual solvent signal $\left[{ }^{1} \mathrm{H}: \delta=2.50 \mathrm{ppm},{ }^{13} \mathrm{C} \delta=39.5 \mathrm{ppm}\right]$. NMR Spectra were recorded at room temperature unless otherwise noted. HPLC analysis was achieved using a Hewlett Packard Series 1050 with a Phenomenex Prodigy 5 ODS-2 column (150 x 4.6mm). The mobile phase was $\mathrm{A}\left(\mathrm{H}_{2} \mathrm{O}+0.1 \% \mathrm{TFA}\right)$ and $\mathrm{B}(\mathrm{MeCN}+0.05 \% \mathrm{TFA})$ used as a linear gradient of 15 to $95 \%$ B over 14 min with a flow rate of $1.5 \mathrm{~mL} / \mathrm{min}$; detection was at $215 \mathrm{~nm}$. Elution times are quoted as $t_{R}$ in min. Values are +/- $0.2 \mathrm{~min}$. Thermospray mass spectra were recorded on an HP5989B Engine, using aqueous ammonium acetate as solvent, with the filament in positive ion mode.

\section{LC-MS Characterization}

\begin{tabular}{|cccc} 
Molecular & $\begin{array}{c}\text { Electrospray } \\
\text { Weight }\end{array}$ & $\mathbf{t}_{R}(\mathbf{m i n})$ & Nmr data \\
\hline 1a & 433.552 & 434 & 3.29 \\
1b & 447.579 & 448 & 3.57 \\
1c & 483.653 & 484 & 3.35 \\
1d & 435.568 & 436 & 3.69 \\
1e & 485.669 & 486 & 3.44 \\
2a & 503.647 & 504 & 2.94 \\
2b & 517.674 & 518 & 3.15 \\
2c & 553.748 & 554 & 2.97 \\
2d & 505.663 & 506 & 3.15 \\
2e & 555.764 & 556 & 3.17 \\
3a & 622.774 & 623 & 3.04 \\
3b & 636.801 & 637 & 3.15 \\
3c & 672.875 & 673 & 3.23 \\
3d & 624.790 & 625 & 3.14 \\
3e & 674.891 & 675 & 3.05
\end{tabular}


$4 a$

444.579

458.606

4c

494.680

446.595

496.695
445

495

447

497
3.2

5.30, d, J = 9Hz, $1 \mathrm{H} ; 4.52, \mathrm{~d}, \mathrm{~J}=7 \mathrm{~Hz}, 1 \mathrm{H} ; 4.86, \mathrm{~m}, 2 \mathrm{H}$; 3.94, m, 1H; 3.82, m, 1H; 3.57, m, $1 \mathrm{H} ; 3.38, \mathrm{~d}, \mathrm{~J}=11 \mathrm{~Hz}$, $1 \mathrm{H} ; 2.96, \mathrm{~m}, 1 \mathrm{H} ; 2.73, \mathrm{~m}, 1 \mathrm{H} ; 2.50, \mathrm{~m}, 1 \mathrm{H} ; 2.18, \mathrm{~m}, 1 \mathrm{H}$; 1.80-2.00, m, 6H; 1.50-1.80, m, 8H, 1.34, m 2H; $1.17, \mathrm{~m}$, $1 \mathrm{H} ; 1.10, \mathrm{~m}, 1 \mathrm{H}, 0.93-1.05, \mathrm{~m}, 10 \mathrm{H}$

\section{Biology}

\section{Fluorogenic (Kobs/l) Assay}

This is a fluorescence resonance transfer assay using $\mathrm{Abz} / \mathrm{NO}_{2} \mathrm{Tyr}$ as the coupling agent. Upon cleavage of a peptide substrate (Aminobenzoyl-E-D-V-V-P-C-S-M-S-Y $\left(3-\mathrm{NO}_{2}\right)-\mathrm{NH}_{2}$ ) there is a signal increase at Em420nm (Ex320nm).

NS3/4A full-length protease was made up to $25 \mathrm{nM}$ in buffer containing the following components: $62.5 \mathrm{mM}$ Hepes $\mathrm{pH} 8.0,0.0625 \%(\mathrm{v} / \mathrm{v}) \mathrm{NP}-40,0.375 \mathrm{M} \mathrm{NaCl}, 12.5 \%(\mathrm{v} / \mathrm{v})$ glycerol, $2.5 \mathrm{mM}$ DTT.

Compound dilutions were performed in 100\% DMSO. 3 concentrations (approximately 5-fold apart) were chosen for each compound such that a Kobs/l value could be determined for each concentration. Appropriately diluted compound $(5 \mu \mathrm{l})$ was pipetted into a single well in a black 96 well flat-bottomed Microtiter plate.

The enzyme mixture, $75 \mu \mathrm{l}$ was added to each well. Substrate $(20 \mu \mathrm{l}, 25 \mu \mathrm{M}$ final concentration) was then immediately added to every well to initiate the reaction. The plate was placed in a FLUOstar reader (BMG LabTechnologies) and read for one hour at room temperature to collect progress plot data. The data was exported to GraFit 4 (Erithacus Software) to obtain a Kobs value for each compound concentration. The Kobs/l value was calculated by dividing the Kobs value by the molar concentration used. Units of measurement are $M^{-}$ ${ }^{1} \mathrm{~s}^{-1}$

\section{Replicon ELISA}

Cells

The 5-15 subline of Huh-7 cells (Lohmann, V., Korner, F., Koch, J-O., Herian, U., Theilmann, L. \& Bartenschlager, R., 1999, Science, 285, pp110-113 ) were used for these assays. These are human hepatocellular carcinoma cells stably transfected with an HCV replicon comprising the majority of the HCV $1 \mathrm{~b}$ genome with the addition of a selectable marker gene, but lacking the genes encoding for all structural proteins and non-structural protein (NS) 2. The replicon RNA is self-replicating and fully functional viral proteins are translated from it. A quantifiable and specific reduction of expressed protein in the presence of a drug can be used as a measure of replicon inhibition.

\section{Compounds}

Stock solutions of compound samples were formulated to $40 \mathrm{mM}$ in DMSO.

\section{Assay Method}


Culture step: $100 \mu \mathrm{l}$ volumes of assay medium (Dulbecco's Minimal Essential Medium \{DMEM\} with 4500mg/L glucose and supplemented with $10 \%$ foetal bovine serum, $100 \mathrm{iu} / \mathrm{mL}$ penicillin, $100 \mu \mathrm{g} / \mathrm{mL}$ streptomycin, $2 \mathrm{mM} \mathrm{L-}$ glutamine and $1 \%$ non-essential amino acids solution) were added to each well of a 96 -well tissue culture plate. The $40 \mathrm{mM}$ stock solutions of compound were further diluted in assay medium to twice the highest final concentration required, and $100 \mu \mathrm{l}$ aliquots were transferred into two wells in the top row of the plate. Serial doubling dilutions were then made down the plate leaving the bottom two rows compound free. A $100 \mu$ l volume of Huh-7 5-15 cell suspension of $2 \times 10^{5}$ cells $/ \mathrm{mL}$ in assay medium was added to all wells. The plates were incubated at $37^{\circ} \mathrm{C}$ in a $5 \% \mathrm{CO}_{2}$ atmosphere for 72 hours.

ELISA step: Growth medium was removed from the plate and the cell monolayers were washed gently once with phosphate buffered saline (PBS) prior to fixing with a 1:1 mix of acetone:methanol for 5 minutes. The plate was washed again with PBS, blotted dry and $100 \mu$ of ELISA diluent (PBS $+0.05 \%$ Tween $20+2 \%$ skimmed milk powder) was added to each well. The plate was incubated at $37^{\circ} \mathrm{C}$ for 30 minutes and the diluent removed. Each well, except one row of the compound free wells, then received $50 \mu \mathrm{l}$ of murine monoclonal antibody, diluted to $1 \mu \mathrm{g} / \mathrm{mL}$, raised to a non-structural protein NS4a. The control row received $50 \mu \mathrm{l} /$ well of diluent alone. The plate was incubated for 2 hours, the primary antibody was removed and the cell sheets washed thoroughly with PBS + 0.05\% Tween 20. Rabbit anti-mouse, polyclonal antibody conjugated to horseradish peroxidase was diluted $1 / 1000$ and $50 \mu \mathrm{l}$ was added to all wells. Following incubation for one further hour, the secondary antibody was

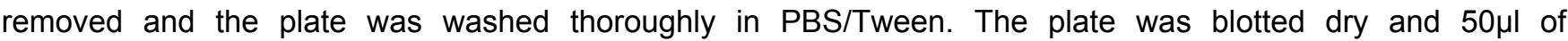
orthophenylene diamine / peroxide substrate in urea buffer was added to all wells and colour development was allowed to proceed at room temperature. The reaction was stopped by the addition of $25 \mu \mathrm{l}$ per well of $2 \mathrm{M}$ sulphuric acid and the plates were read spectrophotometrically at $490 \mathrm{~nm}$.

The ELISA solutions were removed from the plates, and the cell sheets were washed with water, blotted dry and stained with $5 \%$ carbol fuchsin. After 30 minutes the stain was removed and the plates were washed with water and allowed to air dry.

\section{Data analysis}

The absorbence values from all compound-free wells that had received both primary and secondary antibodies were averaged to obtain a positive control value. The mean absorbence value from the compound-free wells that had not received the primary antibody was used to provide the negative (background) control value. The readings from the duplicate wells at each compound concentration were averaged and, after the subtraction of the mean background from all values, were expressed as a percentage of the positive control signal. Grafit software was used to plot the curve of percentage inhibition against compound concentration and derive the $50 \%$ inhibitory concentration $\left(\mathrm{IC}_{50}\right)$ for the compound.

In-assay cytotoxicity was assessed by microscopic examination of the stained cell sheets, and expressed as the lowest compound concentration at which any cytopathic effect was visible.

\footnotetext{
${ }^{2} \mathrm{Nmr}$ characterization data only
} 


\section{Pharmacokinetics}

\section{Dog Cassette Methodology}

Compounds (dosed as a cassette of five test compounds plus an internal standard) were administered intravenously via the femoral vein at a dose level of $0.2 \mathrm{mg} / \mathrm{kg}$ body weight per compound to male beagle dogs in $20 \%$ DMSO, $50 \%$ PEG200, 20\% water. Blood was sampled from the jugular vein over the time period 5 min to $24 \mathrm{~h}$ post dose. Plasma samples were prepared by solid phase extraction. The extracts were analysed by HPLC and detected by single ion monitoring on a Finnigan TSQ mass spectrometer. The analytical column was a Capital Inertsil ODS3 silica $5 \mu \mathrm{m}, 50 \mathrm{~mm} \times 2.1 \mathrm{~mm}$. The mobile phase was $0.1 \%$ formic acid in water:methanol (70:30). The flow rate was $0.4 \mathrm{~mL} / \mathrm{min}$.

\section{Dog Cassette Validation}

Six analogues, whose plasma pharmacokinetics had previously been established in the dog, were coadministered intravenously to a male beagle dog, at a total dose of $1.2 \mathrm{mg} / \mathrm{Kg}$ (i.e. $0.2 \mathrm{mg} / \mathrm{Kg}$ of each component).

As the table shows, there is generally good agreement between the discrete and cassette dosing data, and the ranking of the compounds is similar between protocols also.

\begin{tabular}{lcccccccccccc}
\hline & \multicolumn{2}{c}{$\mathbf{G W 1 6 1 6}^{3}$} & \multicolumn{2}{c}{ GW8330 } & \multicolumn{2}{c}{ GW4890 } & \multicolumn{2}{c}{ GW6968 } & \multicolumn{2}{c}{ GW6966 } & \multicolumn{2}{c}{ GW6217 } \\
\hline & $\mathbf{C}^{4}$ & $\mathbf{D}^{5}$ & $\mathbf{C}$ & $\mathbf{D}$ & $\mathbf{C}$ & $\mathbf{D}$ & $\mathbf{C}$ & $\mathbf{D}$ & $\mathbf{C}$ & $\mathbf{D}$ & $\mathbf{C}$ & $\mathbf{D}$ \\
Dose $\mathrm{mg} / \mathrm{Kg}$ & 0.2 & 0.7 & 0.2 & 0.2 & 0.2 & 0.2 & 0.2 & 0.2 & 0.2 & 0.2 & 0.2 & 0.2 \\
$\begin{array}{l}\text { Clearance } \\
\text { (ml/min/kg) }\end{array}$ & 27 & 28 & 59 & 44 & 46 & 23 & 55 & 65 & 63 & 78 & 91 & 88 \\
Vss (L/kg) & 1.5 & - & 0.6 & 2.7 & 0.5 & 0.5 & 0.4 & 0.4 & 0.3 & 0.3 & 0.05 & 0.06 \\
Varea (L/Kg) & 2 & 3.5 & 1.3 & 4.5 & 0.9 & 0.6 & 1 & 1.7 & 0.8 & 1 & 0.4 & 0.5 \\
Half-life (min) & 52 & 90 & 16 & 72 & 14 & 18 & 12 & 18 & 9 & 10 & 3 & 4 \\
AUCinf (hr.ng/ml) & 122 & 405 & 56 & 77 & 72 & 134 & 61 & 51 & 53 & 43 & 37 & 37 \\
$\begin{array}{l}\text { Plasma Conc (ng/ml) } \\
\text { at 1 h }\end{array}$ & 28 & - & 5 & 13 & 7 & 16 & 3.5 & 1.7 & $<1.25$ & 0.7 & $<1.25$ & $<1.25$ \\
\hline
\end{tabular}

${ }^{3}$ Synonym for GW311616

${ }^{4}$ Cassette dosed

${ }^{5}$ Discrete dosed 


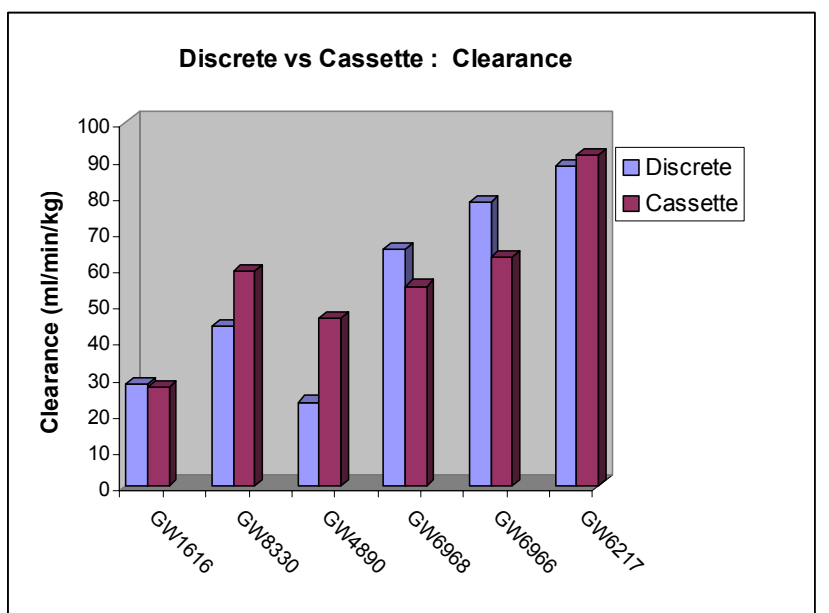

Discrete vs Cassette : Volume of Distribution

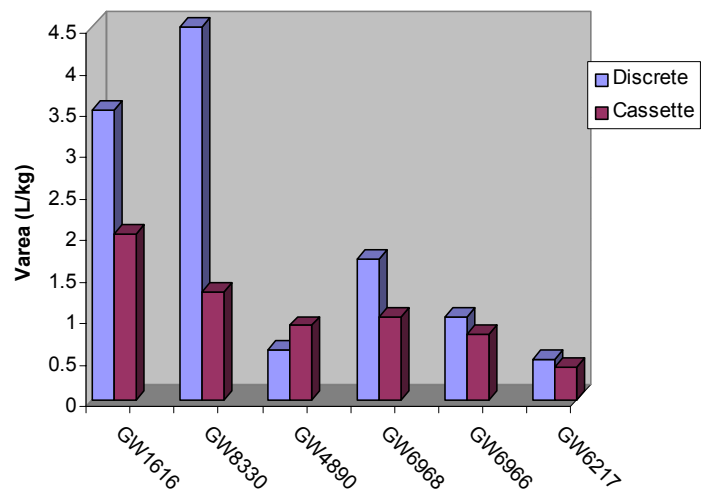

Discrete vs Cassette : Half Life

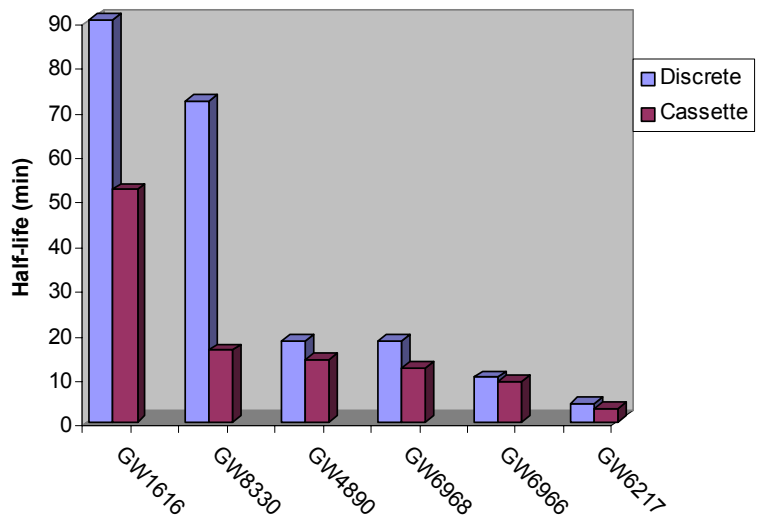


'Right Box' Analysis

1. Clearance data can be recorded as absolute values :

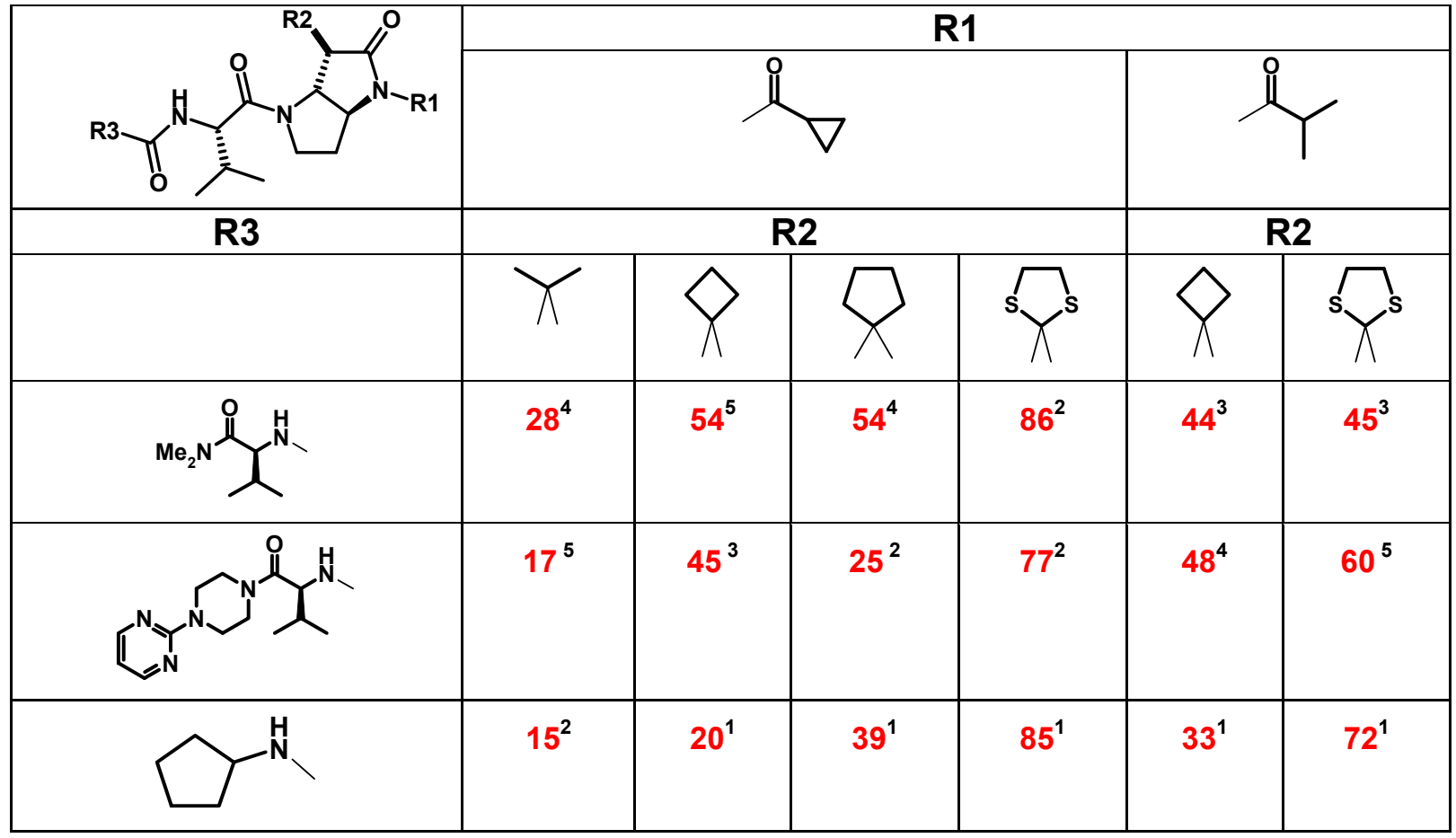

Internal standard Clp (ml/min/kg) : 1 (43); 2 (28); 3 (34); 4 (11); 5 (12);

2. Clearance data can be normalized to the internal standard :

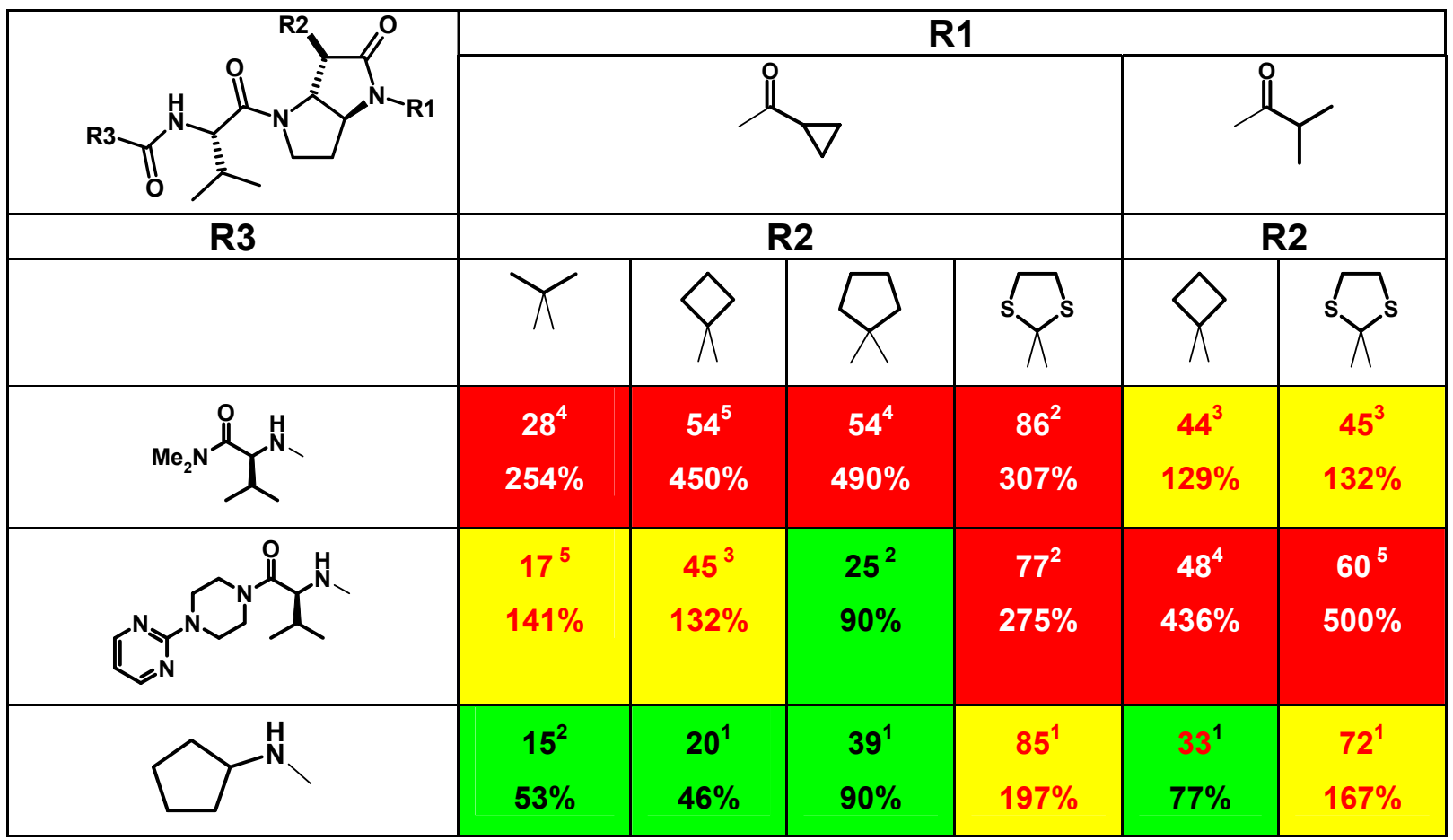

Internal standard Clp (ml/min/kg): 1 (43); 2 (28); 3 (34); 4 (11); 5 (12);

$<100 \%$ of internal ref.

$120-200 \%$ of internal ref.

$>250 \%$ of internal ref. 
3. Compounds can be categorised differently depending on whether absolute or normalized values are used:

Absolute clearance values

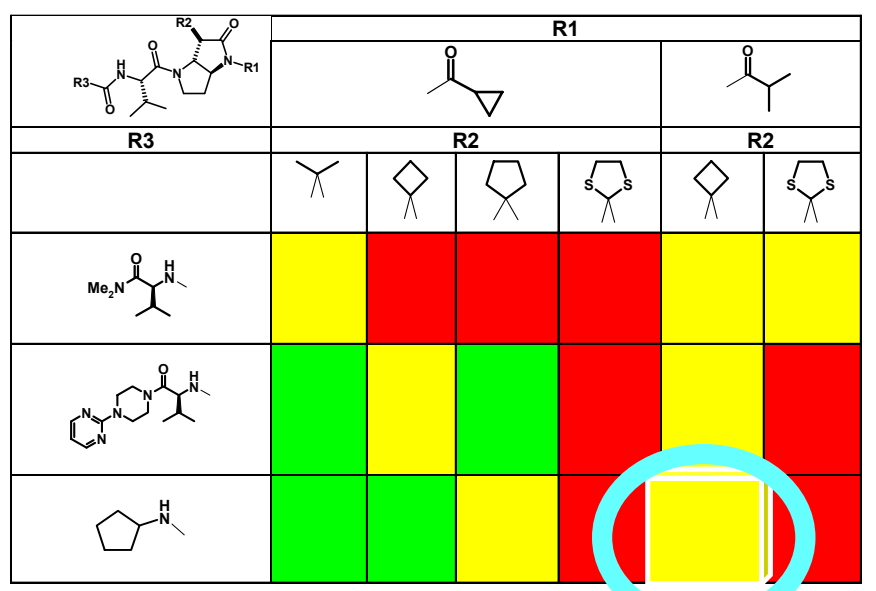

Compound CIp $<25$.

Compound CIp 25-50

Compound Clp $>50$.

\section{Ratios to internal standards}

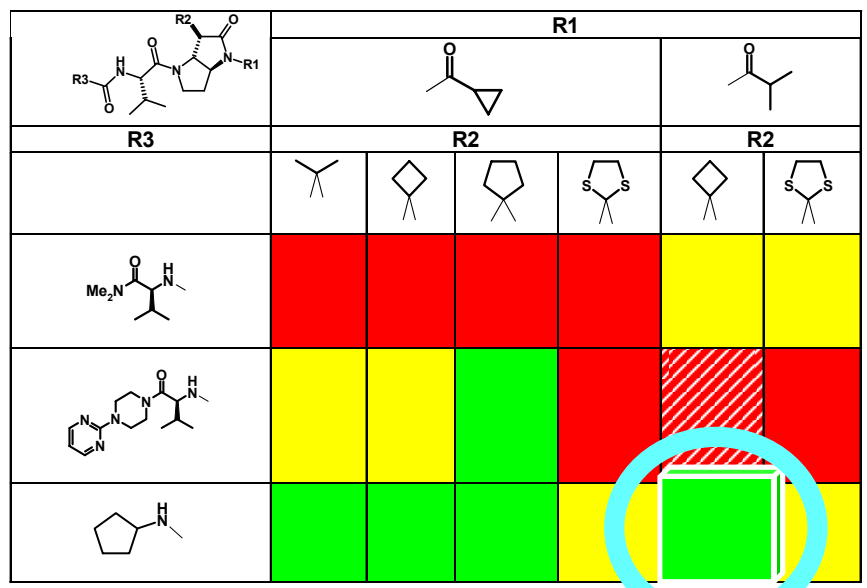

$<100 \%$ of internal ref.

$120-200 \%$ of internal ref. $>250 \%$ of internal ref.

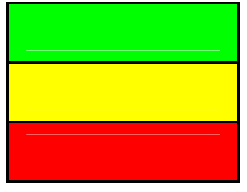

